\title{
VIIIth CEPH Annual Conference
}

Paris, May 25 and 26, 2000, organized by the Fondation Jean Dausset-CEPH

This year, the Conference, entitled 'Genetic History of Modern Humans' will feature four plenum sessions on evolution in primates, phylogeny of modern humans, the HLA system and the genetic diversity of the human population.

The official language of the VIIIth CEPH Annual Conference is English.

\section{Invitation to Submit Abstracts}

Two poster sessions, for young researchers, will be held during the Conference. An abstract should be sent prior to 1st April 2000. From the posters submitted, 8 will be selected by the Scientific Committee for oral presentation and the four best posters will compete for the Prix Hélène Anavi.

The Prix Hélène Anavi was created by Professor Jean Dausset in 1994 to be awarded to a young scientist for outstanding clinical or fundamental research in human genetics. This Prize - amounting to $30,000 \mathrm{FF}$ - is sponsored by the SmithKline Beecham Institute and will be awarded after the Scientific Committee's deliberations on the quality of the presentations.

For further information (programme, how to register, abstract submission):

VIIIth CEPH Annual Conference Secretariat

Fondation Jean Dausset-CEPH

27, rue Juliette Dodu, F-75010 Paris (France)

Tel.: +33 1537250 50, Fax: +33 15372 50 58, E-Mail: conference@cephb.fr, http://www.cephb.fr/

\section{KARGER}

๑) 2000 S. Karger AG, Basel

Fax +41613061234 